\title{
AKHLAK PERILAKU IKLAN DALAM \\ PRESPEKTIP BISNIS ISLAM
}

\author{
Ahmad Edwar ${ }^{1}$ \\ STAI KH. Abdul Kabier Serang-Banten \\ Email: ahmadedwar9@gmail.com \\ Rahma Danti ${ }^{2}$ \\ STAI KH. Abdul Kabier Serang-Banten \\ Email:rahma_danti@gmail.com
}

\begin{abstract}
If a business wants to develop into large, it is necessary as a means of advertising and promotion for the introduction of memory products to the public. In making the ads required elements are very influential in the success of the advertisement so as to boost sales. Business according to fiqh perspective included in muamalah that allows the human to one another conduct transactions or civil relations. In terms muamalah, any activity is allowed as long as no arguments proscribe (al - ashlu fil mu'malah illa al - ibahah ayyadulla dalilun ' ala tahrimiha). Trading activities are permissible in Islam as long as there are no elements that conflict with Personality ' such as the element of maysir, gharar and riba. This means that in sharia marketing, the entire process of creating a good process, bidding process, and the process of change in value there should not be things that are contrary to the contract and the principles of Islamic economic . The extent they can be guaranteed and irregularities muamalah Islamic principles does not occur in a transaction or in the form of business processes in the marketing of any transaction can be allowed Keywords: Ethics, Advertising, Islamic business.
\end{abstract}

Keywords : Ethics, Advertising, Islamic business 
Abstrak : Artikel ini akan membahas akar ideologis jihadis yang menggunakan dalil agama untuk tindakan kekerasan, termasuk terorisme. Secara ideologis kelompok yang berkarak pada paham salafisme atau yang sering disebut dengan wahabisme, yaitu sebuah pemahaman yang menginginkan pemurnian ajaran Islam dengan menolak berbagai interpretasi selain merujuk kepada AlQur'an, hadis nabi dan ucapan sahabat. Meski secara akidah, seluruh fraksi Salafi memiliki kesamaan, namun dalam hal penerapan dan aktualisasi akidah, salafisme terbagi menjadi tiga fraksi yakni salafi puritan, salafi politis dan salafi jihadis. Salafi puritan mewakili kelompok tua yang anti politik, sedangkan kelompok salafi politik kelas menggunakan politik sebagai alat mempertahankan akidahnya, terlebih kelompok jihadis yang menggunakan revolusi dan bahkan tindakan kekerasan dalam menerapkan perinsip-perinsip akidahnya. Isu pokok yang menjadi diskurus dalam paham jihadis antara lain adalah jihad, takfir, dan al-walaa 'wa-l-baraa'.

Kata Kunci : Ideologi Salafi; Salafi Jihadis; Terorisme Keagamaan 


\section{PENDAHULUAN}

Salah satu profesi yang menjadi banyak pilihan adalah berbisnis, dimana hal tersebut merupakan kegiatan yang menghasilkan dan menjual produk atau jasa yang dibutuhkan konsumen pada tingkat keuntungan tertentu. Dan periklanan merupakan salah satu bagian yang tidak terpisahkan dari aktifitas bisnis modern saat ini karena iklan memainkan peranan yang sangat penting untuk menyampaikan informasi (pesan) tentang suatu produk kepada masyarakat. Dalam dunia bisnis, iklan merupakan satu kekuatan yang dapat digunakan untuk menrik konsumen sebanyak-banyaknya. Penekanan utama iklan adalah akses informasi dan promosi dari pihak produsen kepada konsumen. Iklan pada hakikatnya merupakan salah satu strategi pemasaran yang dimaksudkan untuk mendekatkan barang yang hendak dijual kepada konsumen, dengan kata lain mendekatkan konsumen dengan produsen. Sasaran akhir seluruh kegiatan bisnis adalah agar barang yang telah dihasilkan bisa dijual kepada konsumen. Secara positif iklan adalah suatu metode yang digunakan untuk memungkinkan barang dapat dijual kepada konsumen. Serta iklan sebagai salah satu alat pemasaran melalui promosi merupakan proses komunikasi yang bertujuan mempengaruhi minat calon pembeli sehingga mampu memasarkan produknya secara massal. Hampir setiap hari kita dibanjiri oleh iklan yang disajikan media- media massa, baik cetak maupun elekronik. Akibatnya seakan-akan upaya pemenuhan kebutuhan hidup sahari-hari untuk sebagian besarnya dikondisikan oleh iklan. Memang, inilah sebenarnya peran yang diemban oleh iklan, yakni sebagai kekuatan ekonomi dan sosial yang menginformasikan konsumen perihal produkproduk barang dan jasa yang bisa dijadikan sebagai pemuas kebutuhan. Masalah moral dalam iklan muncul ketika iklan kehilangan nilai-nilai normatifnya dan menjadi semata-mata bersifat propaganda barang dan jasa demi profit yang semakin tinggi dari para produsen barang dan jasa maupun penyedia iklan. Kenyataan ini berkaitan erat dengan bagaimana cara industri modern berproduksi yang menghasilkan produk-produk dalam skala besar sehingga mereka harus mencari pembeli. Juga terkait dengan adanya sistem ekonomi pasar, dimana kompetisi merupakan kenyataan yang harus dihadapi, sehingga iklan justru dianggap sebagai salah satu strategi ampuh untuk memenangkan persaingan dalam menguasai pasar yang semakin ketat. Hal tersebut juga tidak bisa lepas dari tujuan periklanan, yaitu membujuk konsumen untuk melakukan sesuatu, yang dalam hal ini biasanya untuk membeli sebuah produk. Agar periklanan dapat menarik dan berkomunikasi dengan khalayaknya dalam cara tertentu sehingga membuahkan hasil yang diinginkan. Dan mereka harus mengakrabkan diri dengan cara berpikir konsumen dengan faktor-faktor yang memotivasi mereka dengan lingkungan dimana mereka hidup. Dan di era sekarang, kebutuhan dan keinginan para konsumen terus berubah. Alhasil, para pembisnis perlu bersungguh-sungguh dalam upaya untuk memasarkan dan menentukan kebutuhan konsumen. Sebab perilaku konsumen menjadi dasar yang amat penting dalam pemasaran dan periklanan. Maka riset konstan terhadap perilaku konsumen dan faktor-faktor yang mempengaruhi perilaku pembelian menjadi sangatlah penting dalam perilaku periklanan. Maka dari itu, persaingan bisnis yang semakin tajam telah memicu munculnya berbagai jenis dan model periklanan yang terkadang jauh dari nilai-nilai etika (moralitas bisnis) dan nilai-nilai kebenaran. Karena strategi ini harus dilakukan agar konsumen mau membeli produk yang ditawarkan, maka iklan yang di tampilkan seringkali terlihat memberikan kesan dan pesan yang berlebihan, dan tidak jarang mengabaikan norma- norma dan nilai-nilai etika 
(morality). Sebagai akibatnya, iklan-iklan tersebut sering menimbulkan citra bisnis yang negatif, bahkan bahkan dianggap menipu. Berangkat dari kenyataan di atas, maka pada bagian ini akan dikaji lebih mendalam persoalan etika dalam periklanan, baik dalam perspektif konvensional maupun Islam. Dan sejauh manakah keterkaitan etika dan iklan? Serta bagaimana Islam melihat persoalan tersebut.

\section{PEMBAHASAN}

\section{Pengertian dan konsep dasar iklan}

Kata iklan (advertising) berasal dari bahasa Yunani. Adapun penegertian iklan secara komprehensif adalah semua bentuk aktivitas untuk mengahadirkan dan mempromosikan ide, barang, atau jasa secara nopersonal yang dibayar oleh sponsor tertentu. (Stewat H. Rewoldt, 1995). Sedangkan menurut Etika (2007) pengertian iklan adalah pesan komunikasi pemasaran atau komunikasi publik tentang sesuatu produk yang disampaikan melalui sesuatu media, dibiayai oleh pemrakarsa yang dikenal serta ditujukan kepada sebagian atau seluruh masyarakat. Jadi, seluruh yang meliputi penyiapan, perencanaan, penyampaian dan umpan balik dari pesan komunikasi pemasaran merupakan adanya informasi kepada konsumer akan keberadaan suatu produk dan "kemampuan" produk tersebut dinamakan periklanan. Iklan merupakan salah satu senjata untuk menaikkan angka penjualan. Iklan juga mempunyai pengaruh besar terhadap citra produk berikut produsennya serta mampu menciptakan kesan yang lengket dibenak konsumennya. Iklan, yang merupakan panduan gambar, kata-kata dan suara, bisa dilihat dari berbagai aspek. Iklan bisa juga dihargai sebagai komoditi yang menggiurkan. Selanjutnya menurut Subagyo Harry Afandi (2004), iklan juga sangat berkaitan erat dengan nilai budaya dan sosial lokal sekaligus humanisme global. Iklan telah menjadi pertukaran luar biasa antara modal ekonomi dengan modal budaya hingga modal sosial yang melahirkan berbagai pencitraan. Maka, iklan tidak saja terkait dengan nilai konsumtif dan selera, namun psikologi komunal terhadap berbagai nilai seperti kebersamaan, semangat, etika dan lainnya. Menyesuaikan pesan iklan dengan selera yang tengah berkembang di masyarakat merupakan strategi komunikasi kepada konsumen. Ada ciri-ciri khas iklan yang dipaparkan oleh Sobagyo Harry Affandi (2004), yaitu:

a. Public presentation (penyajian di muka umum), iklan merupakan suatu sarana komunikasi yang sangat bersifat umum.

b. Pervasivees (penyerahan menyeluruh), iklan merupkan medium yang diserap secara menyeluruh dan memungkinkan pihak perusahaan untuk menaggulangi pesannya itu berulang-ulang.

c. Expresivenes (daya ungkap yang kuat), iklan memberikan peluang untuk menampilkan perusahaan serta produknya dengan cara yang amat mengesankan dengan penggunaan cetakan, bunyi dan warna secara pandai.

d. Impreseonality (kurang kepribadian), iklan senantiasa bersifat umum, daya meyakinkan dan mengungkapkan masih kurang.

Sementara itu diakui ataupun tidak bahwa periklanan atau reklame adalah bagian tak terpisahkan dari bisnis modern. Kenyataan ini berkaitan erat dengan bagaimana cara industri modern berproduksi yang menghasilkan produk-produk dalam kuantitas besar, sehingga harus mencari pembeli. Selain itu ada kaitannya juga dengan sistem ekonomi pasar, dimana kompetisi dan persaingan merupakan unsur hakiki. Dalam hal ini iklan justru dianggap sebagai salah satu cara ampuh 
untuk menonjol dalam persaingan (K. Bertens, 2000). Dan memberikan subsidi kepada media massa sehingga masyarakat bisa menikmati dengan biaya rendah.

Dalam periklanan promosi dilakukan secara tidak langsung dengan melalui media cetak, media elektronik atau media lainnya (papan reklame, spanduk, dan lain-lain), tergantung strategi manajemen pemasaran dan situasi pasar yang sedang dan akan dihadapi. Secara umum menurut Siswanto Sutojo (2002), ada tiga tujuan yang akan dicapai oleh perusahaan dengan program periklanan, yaitu:

1. Iklan informasi Iklan ini secara panjang lebar menerangkan produk dalam tahap rintisan suatu produk untuk menciptakan permintaan pokok atas kategori produk tertentu. Dan memberikan informasi kepada konsumen sasaran tentang produk beserta manfaatnya. Pada tujuan ini, iklan merupakan media untuk menyampaikan informasi yang sebenarnya kepada msyarakat tentang produk yang akan atau sedang ditawarkan di pasar. Pada tujuan ini pula iklan memberikan dan menggambarkan seluruh kenyataan serinci mungkin tentang suatu produk. Sebagai contoh dalam kelompok iklan ini adalah pemberitahuan tentang kehadiran produk baru di pasar, perubahan harga, dan cara penggunaan barang.

2. Iklan Persuasi (membujuk) Iklan ini sebagai pembentuk opini (pendapat umum) yang erat kaitannya dalam persaingan dimana sasaran perusahaan adalah menciptakan permintaan yang selektif akan merek tertentu. Beberapa iklan persuasif menjadi iklan perbandingan yang ingin menciptakan superioritas salah satu merek melebihi merek lain. Iklan yang efektif akan mampu mempersuasi (membujuk) pelanggan untuk mencoba produk atau jasa yang diiklankan. Terkadang persuasi berbentuk mempengaruhi permintaan primer yakni, menciptakan permintaan bagi keseluruhan kategori produk. Lebih sering, iklan berupaya untuk membangun permintaan sekunder, permintaan bagi merek perusahaan yang spesifik.

3. Iklan pengingat Iklan ini sangat penting untuk produk yang berada dalam tahap kedewasaan untuk menjaga agar konsumen selalu ingat akan produk tersebut. Dan mengingatkan kembali pada konsumen akan keberadaan produk di pasar dan berbagai macam manfaat yang dijanjikannya. Saat kebutuhan muncul, yang berhubungan dengan produk yang diiklankan, dampak iklan di masa lalu memungkinkan merek pengiklan untuk hadir di benak konsumen sebagai suatu kandidat merek yang akan dibeli. Lebih jauh iklan ini didemonstrasikan untuk mempengaruhi pengalihan merek (brand switching) dengan mengingatkan para konsumen yang akhir-akhir ini belum membeli suatu merek yang tersedia dan mengandung atribut-atribut yang menguntungkan.

Jadi menurut Muhammad (2004) pada kenyataannya, tujuan iklan merupakan pembentukan citra sebuah produk dan perusahaan di mata masyarakat. Citra ini terbentuk oleh kesesuaian antara kenyataan sebuah produk yang diiklankan dengan informasi yang disampaikan dalam iklan. Maka prinsip etika bisnis yang paling relevan dalam hal ini adalah kejujuran. Dengan demikian, iklan yang membuat pernyataan salah atau tidak benar dengan maksud memperdaya konsumen adalah sebuah tipuan.

\section{A. Persoalan etis dalam iklan}

Secara sederhana, Dewo Sunarno (2006) menyatakan bahwa etika adalah suatu cabang ilmu filsafat yang mencari jawaban atas pertanyaanpertanyaan moral. Etika berisi prinsip-prinsip moralitas dasar yang akan 
mengarahkan perilaku manusia. Dengan semakin kompleksnya masalah moralitas di dunia modern, tidaklah mudah menerapkan dikotomi (benarsalah) pada setiap masalah moral. Setiap masalah dapat dilihat dari berbagai sudut pandang yang dapat menghasilkan pendapat atau penilaian yang berbeda-beda.

Dalam era kontemporer sekarang ini, iklan telah menjadi dunia yang menakjubkan. Iklan telah mengubah komoditi menjadi penanda yang gemerlap. Evolusi dunia industri dimana tadinya iklan hanya sebuah proses mengambil atau memberi perhatian pada sesuatu, telah sampai pada titik dimana iklan seolah menentukan segala sesuatu. Dunia iklan menduduki tempat sentral ketika kpitalisme telah mentransformasikan dunia nyata menjadi dunia citra. Dunia iklan berkembang utuh sebagai sistem terorganisir dari informasi niaga, bujuk rayu, dan citra dari sistem kapitalisme.

Sementara disisi lain juga harus diakui bahwa pemasaran merupakan salah satu urat nadi dalam proses bisnis. Segala macam produksi, output dengan hasil terbaik pun tidak akan optimal diserap oleh konsumen jika tidak melakukan kegiatan pemasaran atau memiliki pemasaran yang bagus. Berbagai macam cara dapat dilakukan dalam mamasarkan suatu produk sehingga sampai di tangan konsumen. Salah satu yang memiliki peranan penting saat ini dalah penggunan iklan. Iklan atau periklanan merupakan bagian yang tak terpisahkan dari bisnis modern. Iklan di anggap sebagai metode yang ampuh untuk menyebarluaskan informasi kepada khalayak mengenai suatu produk yang dihasilkan dalam bisnis. Akan tetapi persaingan bisnis yang semakin tajam memicu munculnya berbagai jenis dan model periklanan yang terkadang jauh dari nilai-nilai etika dan moralitas bisnis serta pesan-pesan kebenaran.

Aneka ragam iklan mulai dari yang ditayangkan secara tradisional melalui media-media cetak maupun melalui media yang lebih modern seperti radio, televisi, internet. Kesemuanya itu sedikit banyak telah meningkatkan penjualan dari produk yang telah ditawarkan oleh suatu unit usaha. Dibalik keberhasilan iklan dalam mendongkrak penjualan produk dalam bisnis, terselip beberapa permsalahan yang bermuara pada persoalan etika. Dimana content serta visualisasi iklan tersebut dianggap sebagai pembodohan serta penipuan terhadap konsumen.

Sedangkan dalam dunia periklanan secara umum Heru Satyanugraha membagi menjadi dua persoalan etis yang saling berkaitan,yaitu:

1. Menyangkut kebenaran akan sebuah iklan.

Pada umumnya periklanan tidak mempunyai reputasi baik sebagai pelindung atau pejuang kebenaran. Kerap kali iklan terkesan suka membohongi, menyesatkan, dan bahkan menipu publik.

2. Manipulasi publik (khalayak).

Hal ini berkaitan dengan segi persuasif dari iklan (tapi juga tidak terlepas dari informasinya). Karena dimanipulasi, seseorang mengikuti motivasi yang tidak berasal dari dirinya sendiri, tapi ditanamkan dalam dirinya dari luar.

Meminjam pernyataannya Siswanto Sutojo (2002), beberapa persoalan etis yang ditimbulkan oleh iklan, khususnya iklan yang manipulatif dan persuasif non-rasional berdampak merugikan masyarakat luas, khususnya konsumen. Iklan manipulatif adalah iklan yang mempengaruhi seseorang sedemikian rupa sehingga orang tersebut tergoda untuk memiliki produk yang 
di iklankan, sedangkan iklan persuasif non-rasional adalah iklan yang mempengaruhi atau memanfaatkan aspek psikologis manusia untuk membuat konsumen tertarik dan terdorong untuk membeli produk tersebut. Daya persuatif tidak terletak pada isi argumen yang bersifat rasional, melainkan pada cara penampilan, yang bahkan sering tidak berhubungan sama sekali dengan produk yang diiklankan.

Sementara itu, menurut Muhammad Djakfar (2002) ada beberapa persoalan etis yang ditimbulkan oleh iklan, khususnya iklan manipulatif dan iklan persuasif non-rasional, diantaranya adalah:

Pertama, iklan merong-rong otonomi dan kebebasan manusia. Artinya, iklan membuat manusia tidak lagi dihargai kebebasannya dalam menentukan pilihannya untuk memperoleh produk tertentu. Banyak pilihan dan pola konsumsi manusia modern sesungguhnya adalah pilihan iklan. Manusia didekte oleh iklan dan tunduk kepada kemauan iklan, khususnya iklan manipulatif dan persuasif non- rasional. Pada fenomena iklan manipulatif, manusia benar-benar menjadi objek untuk mengeruk keuntungan sebesarbesarnya dan tidak sekedar diberi informasi untuk memebantunya memilih produk tertentu.

Kedua, dalam kaitan dengan itu iklan manipulatif dan persuasif nonrasional menciptakan kebutuhan manusia dengan akibat manusia modern menjadi konsumtif. Secara ekonomis hal itu baik karena akan menciptakan permintaan dan ikut manaikkan daya beli masyarakat, bahkan dapat memacu produktifitas kerja manusia hanya demi memenuhi kebutuhan hidupnya yang terus bertambah dan meluas. Namun dipihak lain muncul masyarakat konsumtif, dimana banyak dari yang dianggap manusia sebagai kebutuhannya yang sebenarnya bukan kebutuhan hakiki.

Ketiga, yang juga menjadi persoalan etis yang serius adalah bahwa iklan manipulatif dan persuasif non-rasional malah membentuk dan menentukan identitas atau ciri dari manusia modern. Manusia modern merasa belum menjadi dirinya kalau belum memiliki barang sebagaimana ditawarkan dalam iklan. Identitas manusia modern hanyalah identitas misal: serba sama, serba tiruan, serba polesan, dan serba instant. Manusia mengkonsumsi produk yang sama, maka jadilah identitas manusia modern yang hanya menjadi rancangan pihak tertentu di fabricated. Yang di pujapun lebih banyak berkesan luar, polesan, dan kepura-puraan.

Keempat, bagi masyarakat modern, tingkat perbedaan ekonomi dan sosial yang tinggi akan merong-rong rasa keadilan sosial masyarakat. Iklan yang menampilkan yang serba mewah sangat ironis dengan kenyataan sosial, dimana banyak anggota masyarakat masih berjuang sekedar hidup. Iklan yang mewah tampil sekan-akan tanpa punya rasa solidaritas dengan sesama yang miskin.

Kendati dalam kenyataan praktis sulit menilai secara umum etis tidaknya iklan tersebut, Yusuf Qrdlawi (1995) memaparkan beberapa prinsip yang kiranya perlu diperhatikan dalam iklan, yaitu:

Pertama, iklan tidak boleh menyampaikan informasi yang palsu dengan maksud untuk memperdaya konsumen. Masyarakat dan konsumen tidak boleh diperdaya oleh iklan untuk membeli produk tertentu. Mereka juga tidak boleh dirugikan hanya karena telah diperdaya oleh iklan tertentu.

Kedua, iklan wajib menyampaikan semua informasi tentang produk tertentu, khususnya menyangkut keamanan dan keselamatan manusia. 
Ketiga, iklan tidak boleh mengarah pada pemaksaan, khususnya secara kasar dan terang-terangan.

Keempat, iklan tidak boleh mengarah pada tindakan yang bertentangan dengan moralitas: tindak kekerasan, penipuan, pelecehan seksual, diskriminasi, perendahan martabat manusia dan sebagainya.

Sebagai salah satu "jembatan" yang terpenting dalam etika perilaku periklanan adalah bagaimana inti pesan dalam suatu iklan dapat diterima dengan baik oleh semua pihak yang terlibat. Di sinilah etika muncul. Etika komunitas periklanan memang dapat dimaklumi sifatnya membatasi ruang gerak para pelaku usaha. Pembatasan itu bertujuan positif agar seluruh pihak yang terkait dapat melakukan usahanya dengan sebaik mungkin tanpa harus merugikan salah satu pihak terkait.

Memang secara sepintas, dua istilah antara "etika" dan "iklan" nampaknya memang jauh berbeda dan tidak terkait satu sama lainnya. Akan tetapi, menurut KTI. Mualim (2001) sesungguhnya antara keduanya terdapat kaitan yang erat. Etika merupakan suatu pedoman perilaku yang mempengaruhi harapan untuk berperilaku sosial sesuai dengan konvensi norma yang berlaku dalam suatu kelompok sosial tertentu. Karena etika menjangkau proses berpikir dan suara-hati dalam menentukan suatu pendapat atau perilaku. Sementara iklan harus bersifat komunikatif kepada khalayak agar dapat diterima, dan iklan juga harus perlu mengetahui "consumer insight" yang akan sangat erat kaitannya dengan nilai-nilai budaya. Dimana sebuah etika juga disusun berdasarkan nilai-nilai budaya dari khalayak.

Jadi dalam hal ini jelas bahwa etika dan iklan mempunyai relevansi yang sangat erat sekali. Kepuasan konsumen atas sebuah produk tergantung pada kejujuran iklan yang ditayangkan karena konsumen tidak hanya sekedar ingin memenuhi kebutuhan, akan tetapi ia juga mengharap kepuasan. Sebab sebagaimana diutarakan oleh Philip Kotler dan Gary Amstrong (1997), bahwa tujuan dari periklanan itu sendiri untuk membujuk konsumen melakukan pembelian suatu produk atau jasa. Karena itulah riset perilaku konsumen yang didasarkan pada faaktor budaya, sosial, pribadi serta psikologis menjadi faktor yang sangat penting dalam menganalisis kebutuhan dan karakteristik pembelian konsumen. Dan etika merupakan "negative consumer insight", yaitu suatu pagar yang membatasi kreatifitas agar pesan komunikasi tidak di tolak oleh khalayak.

\section{B. Periklanan dalam perspektif etika Islam}

Etika bisnis sebagai seperangkat nilai tentang baik, buruk, dan salah dalam dunia bisnis berdasarkan pada prinsip-prinsip moralitas. Dalam arti lain etika bisnis berarti seperangkat prinsip dan norma dimana para pelaku bisnis harus komit padanya dalam bertransaksi, berperilaku, dan berelasi guna mencapai tujuan-tujuan bisnisnya dengan selamat.

Secara normatif bagi R. Lukman Fauroni (2002), etika dalam AlQuran belum memperlihatkan sebagai suatu struktur yang berdiri sendiri dan terpisah dari sruktur lainnya, sebagaimana terpahami dari ilmu dan akhlaq. Struktur etika dalam Al-Quran lebih banyak menjelaskan tentang nilai-nilai kebaikan dan kebenaran baik pada tataran niat atau ide hingga perilaku dan perangai. Hal ini lebih tegas lagi bila dilihat dari penggambaran sikap dan perilaku Nabi Muhammad SAW yang disebut Al-Quran sebagai memiliki akhlak yang agung. Keberadaan nilai-nilai ini bersifat terbuka, menjelajah memasuki semua lini bidang kehidupan. Etika bisnis dalam Al-Quran dari 
sudut pandang ini, tidak hanya dapat dilihat dari aspek etika secara parsial, karena bisnis pun dalam pandangan Al- Quran telah menyatu dengan nilainilai etika itu sendiri. Al-Quran secara jelas menggambarkan perilaku-perilaku bisnis yang tidak etis, yang dapat ditelusuri dari muara kebatilan dalam bisnis.

Dan Islam adalah agama yang sempurna (kamil) serta universal (mutakamil). Ajaran Islam meliputi seluruh aspek kehidupan manusia. Tidak ada satupun sendi kehidupan manusia yang lepas dari pandangan Islam. Demikian pula Islam mengatur masalah-masalah ekonomi. Betapa banyaknya ayat-ayat al-Quran maupun hadits nabi yang mengungkapkan tentang masalah tersebut. Diantaranya Islam juga membicarakan masalah etika. Sebagai konsekuensinya dalam setiap kegiatan ekonomi, yang dilakukan seseorang harus sesuai dengan aturan-aturan yang telah ditentukan dalam Islam agar mendapat ridlo dari Alloh SWT.

Bagi seorang muslim, kemapanan paradigma konvensional akan arti manusia sebagai "homo economic" (pelaku ekonomi yang mencari keuntungan bagi dirinya tanpa mengindahkan kepentingan orang lain) tidak sepenuhnya sesuai dengan nilai-nilai etika Islam. Oleh sebab itu, morality concept dalam perspektif Islam diusung pada saat pencerahan aksiomaaksioma yang sudah terlanjur kondang (dari sistem kapitalis misalnya). Alhasil, apresiasi manusia umum akan materi pelan-pelan harus digeser melalui arahan rambu imperative syariah. Pergeseran nilai ini diharapakan dapat membantu bentukan sistem aplikasi manual dari mekanisme produk ekonomi syariah, karena muatan 'tercerah' dan perspektif ini adalah adanya dimensi moral berbasis wahyu. (Faisal Badroen, 2006).

Senada dengan pernyataan diatas, Yusuf Qardlawi (1995) mengatakan, dalam pandangan Islam, setiap individu maupun kelompok, di satu sisi diberikan kebebasan untuk mendapatkan keuntungan sebesar- besarnya, akan tetapi di sisi lain ia terikat dengan iman dan etika sehingga ia tidak bebas mutlak dalam menginvestasikan modalnya (berbisnis) atau membelanjakan hartanya.

Oleh sebab itu masyarakat Islam tidak bisa bebas tanpa kendali dalam melakukan berbagai kegiatan ekonomi, namun ia selalu terikat dengan normanorma agama yang disebut dengan etika atau akhlak. Sementara dalam kajian fiqih Islam, Muhammad Djakfar (2002) memaparkan, bahwasannya kebenaran dan keakuratan informasi ketika seorang pelaku usaha mempromosikan barang dagangannya menempati kajian yang sangat signifikan. Islam tidak mengenal sebuah istilah kapitalisme klasik yang berbunyi "caveat emptor" atau "let the buyer beware" (pembelilah yang harus berhati-hati), tidak pula "cevent vendotor" (pelaku usahalah yang harus berhati-hati). Tetapi dalam Islam yang berlaku adalah prinsip keseimbangan (al-ta'adul) atau ekuilibrium dimana pembeli dan penjual harus berhati-hati dalam hal teori perjanjian (nadzariyyat al-'uqud) dalam Islam.

Sebagaimana terkait dengan prinsip-prinsip dasar etika bisnis Islam yang dikemukakan Faisal Badroen (2006) yaitu:

1. Unity (persatuan) Konsep tauhid (dimensi vertikal) dimana Alloh sebagai Tuhan Yang Maha Esa menetapkan batas-batas tertentu atas perilaku manusia sebagai khalifah, untuk memberikan manfaat pada individu tanpa mengorbankan hak-hak individu lainnya. Hak-hak dan kewajiban ekonomi setiap individu disesuaikan dengan kapabilitas dan kapasitas yang dimiliki dan sinkronisasi pada setiap peranan normatif masing- masing dalam 
struktur sosial. Dan Islam tidak mengakui adanya kelas- kelas sosio ekonomis sebagai sesuatu yang bertentangan dengan prinsip persamaan maupun dengan prinsip persaudaraan (ukhuwah). Karena mematuhi ajaran-ajaran Islam dalam semua aspeknya dianggap sebagai untuk mendpatkan Ridlo Allah SWT.

2. Equilibrium (keseimbangan) Dalam beraktifitas di dunia kerja dan bisnis, Islam mengharuskan untuk berbuat adil, tak terkecuali kepada pihak yang tidak disukai. Pengertian adil dalm Islam diarahkan agar hak orang lain, hak lingkungan sosial, hak alam semesta dan hak Alloh serta Rosulnya berlaku sebagai stakeholder dari perilaku adil seseorang. Manusia memeiliki kesamaan dan keseimbangan dalam kesempatannya, dan setiap individu bisa mendapatkan keuntungan itu sesuai dengan kemampuannya (kapabilitas dan kapasitas). Individu-individu dicipta (oleh Alloh) dengan kapabilitas, keterampilan, intelektualitas dan talenta yang berbeda-beda. Manusia secara intensif diperintah untuk hidup bersama, bekerja sama dan saling tolong menolong memanfaatkan keterampilan mereka masingmasing.

3. Free Will (kehendak bebas) Konsep Islam memahami bahwa institusi ekonomi seperti pasar dapat berperan efektif dalam kehidupan ekonomi. Hal ini dapat berlaku bila prinsip persaingan bebas dapat berlaku secara efektif, dimana pasar tidak mengharapkan adanya intervensi dari pihak manapun. Tak terkecuali Negara dengan otoritas penentuan harga atau privat sector dengan kegiatan monopolistik

4. Responsbility (tangung jawab) Penerimaan pada prinsip tangung jawab individu ini berarti setiaporang akan diadili secara personal di hari kiamat kelak. Tidak ada satu cara pun bagi seseorang untuk melenyapkan perbuatan-perbuatan jahatnya kecuali dengan memohon ampunan kepada Allah dan melakukan perbuatan-perbuatan yang baik (amal sholeh). Islam tidak mengenal konsep dosa wrisan, dan tidak ada seorang pun bertangung jawab atas kesalahan-kesalahan orang lain.

5. Benevolence (ihsan) Yaitu melaksanakan perbuatan baik yang dapat memberikan kemanfaatan kepada orang lain, tanpa adanya kewajiban tertentu yang mengharuskan perbuatan tersebut atau dengan perkataan lain beribadah dan berbuat baik seakan-akan melihat Allah, jika tidak mampu maka yakinlah Allah melihat. Kendati Al-Quran mendeklarasikan bahwa bisnis adalah hal halal, namun demikian setiap perikatan ekonomi yang dilakukan dengan orang lain, tidak membenamkan dirinya dari ingatan kepada Allah dan pelaksanaan setiap perintah-Nya. Seorang muslim diperintahkan untuk selalu ingat kepada Allah, baik dalam kondisi bisnis yang sukses atau dalam kegagalan bisnis.

Aktivitas bisnis harus pula konsisten dengan sistem moral yang terkandung di dalam Al-Quran. Orang muslim yang beriman harus bekerja keras untuk mendapatkan fasilitas terbaik di akhirat kelak, dengan cara memanfaatkan setiap karunia yang diberikan Allah di muka bumi ini. Sementara itu iklan adalah sarana untuk melakukan promosi. Promosi merupakan salah satu marketing mix (bauran pemasaran). Pemasaran menurut perspektif syariah adalah segala aktivitas bisnis dalam bentuk kegiatan penciptaan nilai (value-creating-ctvities) yang memungkinkan pelakunya bertumbuh serta mendayagunakan kemanfaatannya yang dilandasi dengan kejujuran, keadilan, keterbukaan, dan keihklasan sesuai proses yang 
berprinsip pada akad bermuamalah Islami. Dalam konteks etika pemasaran yng bernuansa Islami, dapat dicari pertimbangan dalam Al-Quran. Al-Quran memberikan dua persyaratan dalam proses bisnis yakni persyaratan horizontal (kemanusiaan) dan persyaratan vertical (spiritual).

Sebagaimana firman Allah SWT dalam QS. Al-Baqarah: 1-2, yang artinya: "Kitab (Al-Quran) ini tidak ada yang diragukan didalamnya. Menjadi petunjuk bagi orang-orang yang bertakwa". Isyarat diatas sangat relevan dijadikan sebagai pedoman dalam melakukan proses marketing, sebab marketing merupakan bagian yang sangat penting dan menjadi mesin suatu perusahaan. Maka dengn mengambil petunjuk yang dijelskan Allah dalam AlQuran, maka dalam angka penjulan itupun kita harus dapat memberikan jaminan bagi produk yang kita miliki.

\section{PENUTUP}

Ketika bisnis ingin berkembang menjadi besar, maka diperlukan iklan sebagai sarana promosi untuk pengenalan dan daya ingat produk kepada masyarakat. Dalam pembuatan iklan diperlukan unsur-unsur yang sangat berpengaruh dalam keberhasilan iklan sehingga mampu mendongkrak penjualan. Bisnis menurut perpektif ilmu fiqih termasuk dalam mumalah yang memperbolehkan antara manusia satu dengan yang lain melakukan transaksi atau hubungan perdata.

Dalam hal bermuamalah, kegiatan apapun diperbolehkan sepanjang tidak ada dalil yang mengharamkannya (al-ashlu fil-mu'malah al-ibahah illa ayyadulla dalilun 'ala tahrimiha). Kegiatan jual beli adalah dihalalkan dalam Islam selama tidak ada unsur yang bertentangan dengan syara' semisal adanya unsur maysir, gharar, dan riba. Ini artinya bahwa dalam syariah marketing, seluruh proses baik proses penciptaan, proses penawaran, maupun proses perubahan nilai (value) tidak boleh ada hal-hal yang bertentangan dengan akad dan prinsip- prinsip muamalah yang Islami. Sepanjang hal tersebut dapat dijamin dan penyimpangan prinsip-prinsip muamalah Islami tidak terjadi dalam suatu transaksi atau dalam proses bisnis maka bentuk transaksi apapun dalam pemasaran dapat diperbolehkan.

\section{DAFTAR PUSTAKA}

Badroen, Faisal, Eika Bisnis dalam Islam, Jakarta: Kencana, 2006

H. Rewoldt, Stewart, Strategi Promosi Pemasaran, Jakarta: Rineka Cipa, 1995

K. Bertens, Pengantar Etika Bisnis, Yogyakarta: Kanisius, 2000

Kotler, Philip, Manajemen Pemasaran di Indonesia, Jakarta: Salemba, 1997

Mualim, KTI, Peranman Etika dalam Sistyem Perekonomian, Jakarta: Gema Insani, 2001

Muhammad, Ekonomi Mikro dalam Perspektif Islam, Yogyakarta: Fakultas Ekonomi UGM, 2004

Muhammad, Fouron, R. Lukman, Visi Al-Qur'an Tentang Etika dan Bisnis, Jakarta: Salemba Diniya, 2002

Qordlawi, Yusuf, Norma dan Etika Islam, Jakatya: Gema Insani Press, 1997 
Akhlak Perilaku IKLan Dalam...

Subagyo, Slamet, Harry Affand, Mendongkrak omzet Penjualan dengan Iklan, Semarang: Gritama, 2004 Sutojo, Siswanto, Strategi Manajemen Pemasaran, Jakarta: Dammar Mulia Pustaka, 2002 